Article

\title{
Impact of Temperature on Survival Rate, Fecundity, and Feeding Behavior of Two Aphids, Aphis gossypii and Acyrthosiphon gossypii, When Reared on Cotton
}

\author{
Jinping Liu ${ }^{1}\left(\mathbb{D}\right.$, Chen Wang ${ }^{1}$, Nicolas Desneux ${ }^{2}$ and Yanhui Lu ${ }^{1, *} \mathbb{C}$ \\ 1 State Key Laboratory for Biology of Plant Diseases and Insect Pests, Institute of Plant Protection, \\ Chinese Academy of Agricultural Sciences, Beijing 100193, China; jinping_liu21@163.com (J.L.); \\ chenwang_wc@163.com (C.W.) \\ 2 Université Côte d'Azur, INRAE, CNRS, UMR ISA, 06000 Nice, France; nicolas.desneux@sophia.inra.fr \\ * Correspondence: luyanhui@caas.cn
}

Citation: Liu, J.; Wang, C.; Desneux, N.; Lu, Y. Impact of Temperature on Survival Rate, Fecundity, and Feeding Behavior of Two Aphids, Aphis gossypii and Acyrthosiphon gossypii, When Reared on Cotton. Insects 2021, 12, 565. https://doi.org/10.3390/ insects12060565

Academic Editor: Hervé Colinet

Received: 6 May 2021

Accepted: 17 June 2021

Published: 21 June 2021

Publisher's Note: MDPI stays neutral with regard to jurisdictional claims in published maps and institutional affiliations.

Copyright: (c) 2021 by the authors. Licensee MDPI, Basel, Switzerland. This article is an open access article distributed under the terms and conditions of the Creative Commons Attribution (CC BY) license (https:// creativecommons.org/licenses/by/ $4.0 /)$.
Simple Summary: Understanding the effects of high temperature on pest insects is important in predicting their population dynamics. Aphis gossypii (Glover) and Acyrthosiphon gossypii (Mordviiko) are the two most destructive aphids on cotton in Xinjiang Province, China. This study examined the effect of different temperatures $\left(29^{\circ} \mathrm{C}, 32^{\circ} \mathrm{C}\right.$, and $\left.35^{\circ} \mathrm{C}\right)$ on the adult survival rate, fecundity, and feeding behavior of Ap. gossypii and Ac. gossypii. Our results showed that the adverse effects of high temperatures $\left(32{ }^{\circ} \mathrm{C}, 35^{\circ} \mathrm{C}\right)$ on aphid adult survival and fecundity were greater for Ac. gossypii than Ap. gossypii. Feeding data showed that Ac. gossypii spent more time feeding on xylem than phloem under all temperature treatments, which contrasted with $A p$. gossypii. The time of phloem ingestion by Ap. gossypii at $32{ }^{\circ} \mathrm{C}$ was significantly higher than at $29^{\circ} \mathrm{C}$, while for Ac. gossypii, this value significantly decreased when temperature increased. These feeding patterns indicate that Ac. gossypii obtains less nutrition from phloem in support of its development and fecundity. Data generated in this study will serve as the basis for predicting the effect of increased temperature on these two cotton aphids.

Abstract: Aphid performance is sensitive to temperature changes. Previous studies found that Acyrthosiphon gossypii (Mordviiko) was more sensitive to high temperature than Aphis gossypii (Glover). However, the effects of high temperatures on the survival, fecundity, and feeding behavior of these two aphid adults are not clear. This study examined the effect of different temperatures $\left(29^{\circ} \mathrm{C}, 32^{\circ} \mathrm{C}\right.$, and $35{ }^{\circ} \mathrm{C}$ ) on the adult survival rate, fecundity, and feeding behavior of these two aphid species. Our results showed that the adverse effects of high temperatures $\left(32^{\circ} \mathrm{C}\right.$ and $\left.35^{\circ} \mathrm{C}\right)$ on aphid adult survival and fecundity were greater for Ac. gossypii than Ap. gossypii. The electrical penetration graph (EPG) data showed that Ac. gossypii spent more time feeding on xylem than phloem under all temperature treatments, which contrasted with Ap. gossypii. The time of phloem ingestion by $A p$. gossypii at $32{ }^{\circ} \mathrm{C}$ was significantly higher than at $29^{\circ} \mathrm{C}$, while for Ac. gossypii, this value significantly decreased when temperature increased. These feeding patterns indicate that Ac. gossypii obtains less nutrition from phloem in support of its development and fecundity. Data generated in this study will serve as the basis for predicting the effects of increased temperature on these two cotton aphids.

Keywords: climate change; high temperature; cotton aphid; electrical penetration graph; adaptability

\section{Introduction}

As one of most important current environmental issues, global warming is of wide concern. The mean global temperature increased by $0.72{ }^{\circ} \mathrm{C}$ from 1880 to 2012 , and it is predicted to rise an additional $1.1^{\circ} \mathrm{C}$ to $6.4^{\circ} \mathrm{C}$ by the end of the 21 st century [1,2]. Such climate changes present a major challenge for poikilotherms such as insect herbivores [3]. Most previously published studies have found that increases in atmospheric temperature directly 
affect life cycles, phenology, behavior, and distribution of insect herbivores, or indirectly affect insects through other factors that respond to temperature-induced changes [4-7]. For example, even moderate increases of ambient temperature can enhance the population growth rates of some insect herbivores, resulting in more generations per year [8,9]. A higher temperature in spring or winter can modify the normal developmental time and the overwintering of insects [10]. An increase in night-time temperature $\left(>20^{\circ} \mathrm{C}\right)$ can reduce the survival and fecundity of English grain aphid, Sitobion avenae (Fabricius) [11]. In addition, S. avenae avoids heat stress by dropping off its host plant [6], which interrupts feeding. The field occurrence and period of migration of Aphis gossypii (Glover) have both increased historically along with climate warming based on a period of about 60 years of literature data [12]. Species may respond differently to rising temperatures, and the degree of change species undergo may depend on their individual ability to adapt to high temperature, whether through rapid evolution or high plasticity [13]. Changes in insect herbivores' performance under climate warming conditions may affect agricultural production strategies and pest control. Therefore, it is of great importance to study the effects of temperature on insects as a basis for predicting the future status of insect pests.

Aphids have a small body size and their development, survival, and reproduction are sensitive to changes in ambient temperature [11,14]. Aphis gossypii is a highly polyphagous pest infesting nearly 100 crop species throughout the world [15]. The crops damaged by Ap. gossypii include cotton, cucurbits, citrus, coffee, cocoa, aubergine, peppers, potato, and okra, as well as many ornamental plants. Acyrthosiphon gossypii (Mordviiko) has a narrower range of distribution in China compared with Ap. Gossypii, being found only in Xinjiang and Gansu provinces. Acyrthosiphon gossypii damages legumes and cotton [16]. In Xinjiang Province, both Ap. gossypii and Ac. gossypii co-occur as important pests of cotton [17]. However, Ap. gossypii may occur in the seedling, flowering, and boll stage of cotton growth, while Ac. gossippii generally occurs in the seedling stage [18].

Previous studies indicate that Ap. gossypii and Ac. gossypii respond differently to high temperature [17]. For Ap. gossypii, Kersting et al. [19] reported that the net reproduction rate $\left(R_{0}\right)$ was 37.9 at a constant $30{ }^{\circ} \mathrm{C}$, while $35^{\circ} \mathrm{C}$ was lethal to $A p$. gossypii nymphs reared on cotton. However, some studies have demonstrated that the first instars of nymph of Ap. gossypii reared on cotton and cucumber can successfully survive to the adult stage and produce progeny at a constant $35^{\circ} \mathrm{C}$ [20-23]. The host plant species and aphid genotype may explain this difference in the value of the upper lethal temperature for Ap. gossypii.

In comparison, Ac. gossypii nymphs can successfully survive to adult stage at constant $30{ }^{\circ} \mathrm{C}$, but female adults fail to produce offspring [18]. Although earlier studies have tested the impact of constant temperatures on the developmental time and fecundity of Ap. gossypii and Ac. gossypii reared on cotton $[16,19,20,23]$, most of these studies started with first instar nymphs in each temperature. These studies show that temperature may affect nymphal instars differently [24], and clearly the adult stage, not considered in many of these earlier studies, plays important population roles in the areas of reproduction and dispersal. Therefore, the impact of increasing temperature on Ap. gossypii and Ac. gossypii needs to be studied more holistically by including adult responses, together with that of each separate instar.

The feeding behavior of aphids can be affected by the nutritional quality of the phloem sap of the plants on which they feed. Phloem quality itself can be affected by climate change [25-28]. Jiang et al. [29] found that the time of stylet penetration to phloem position and the mean frequency of xylem phase of Ap. gossypii were significantly reduced under elevated $\mathrm{CO}_{2}$ because of increased soluble proteins in the cotton leaves. The feeding efficiency of Myzus persicae (Sulzer) increased under elevated $\mathrm{CO}_{2}$ owing to up-regulation of mitogen-activated protein kinases (MPK4) in the host plant [27]. The xylem absorption time of Acyrthosiphon pisum (Harris) was increased to deal with high osmotic pressure of phloem sap under drought stress [25]. Because aphids vector many plant viruses [30], the details of aphid feeding behavior are important because any changes may affect the virus' transmission rate [31]. Therefore, studies of feeding behavior of aphids under elevated 
temperature are helpful in predicting changes in the transmissibility of plant viruses. Currently, such information regarding the impact of temperature on the feeding behavior patterns of Ap. gossypii and Ac. gossypii is not available. It is not known whether or not the impacts of high temperatures on the feeding behaviors of these two long-coexisting aphids will be similar.

The electrical penetration graph (EPG) technique has been used to monitor the probing behavior and location of stylet tips in the host tissue of the sucking insect for a long time [32]; the results can help us to identify the host preference [33,34], host resistance [35], and position of host resistance [36] to insects. Here, our specific goals were (i) to compare the survival rates, longevity, and fecundity of adult females of Ap. gossypii and Ac. gossypii at different temperatures $\left(29^{\circ} \mathrm{C}, 32^{\circ} \mathrm{C}\right.$, and $\left.35^{\circ} \mathrm{C}\right)$ and (ii) to use the electrical penetration graph (EPG) technique to investigate the feeding behaviors of Ap. gossypii and Ac. gossypii among these temperatures. These data will provide a necessary basis for predicting the effects of increased temperature on the performances of these two cotton aphids.

\section{Materials and Methods}

\subsection{Aphids Sources and Host Plants}

Aphis gossypii and Ac. gossypii were collected from cotton fields on Korla Experimental Station, Chinese Academy of Agricultural Sciences (CAAS; $41.45^{\circ} \mathrm{N}, 85.48^{\circ}$ E) (Korla, Xinjiang Province) on 21 June 2019. We identified the two aphid species based on the morphological characteristics described in Li [37]. The adults are shown in Figure 1. The cotton field was maintained without any pesticide before aphids were collected. Aphids were reared on young cotton leaves in a controlled climatic chamber at $29 \pm 1{ }^{\circ} \mathrm{C}, 50 \pm 5 \%$ $\mathrm{RH}$, and 16:8 (L/D) h photoperiod at the Langfang Experimental Station, Chinese Academy of Agricultural Sciences (CAAS; $39.53^{\circ} \mathrm{N}, 116.70^{\circ}$ E) (Langfang, Hebei Province). The Gossypium hirsutum L. cultivar Zhongmian 49 was used in this study. Cotton plants were grown from seeds in plastic cups (top diameter, $120 \mathrm{~mm}$; bottom diameter, $90 \mathrm{~mm}$; height, $100 \mathrm{~mm}$ ) containing peat, vermiculite, and field soil (volume ratio: 6:1:1) in a greenhouse at $28-30{ }^{\circ} \mathrm{C}, 50 \pm 5 \% \mathrm{RH}$, and 16:8 (L/D) h photoperiod. Cotton plants were used for the feeding behavior experiment at the 4 - to 5-leaf stage.

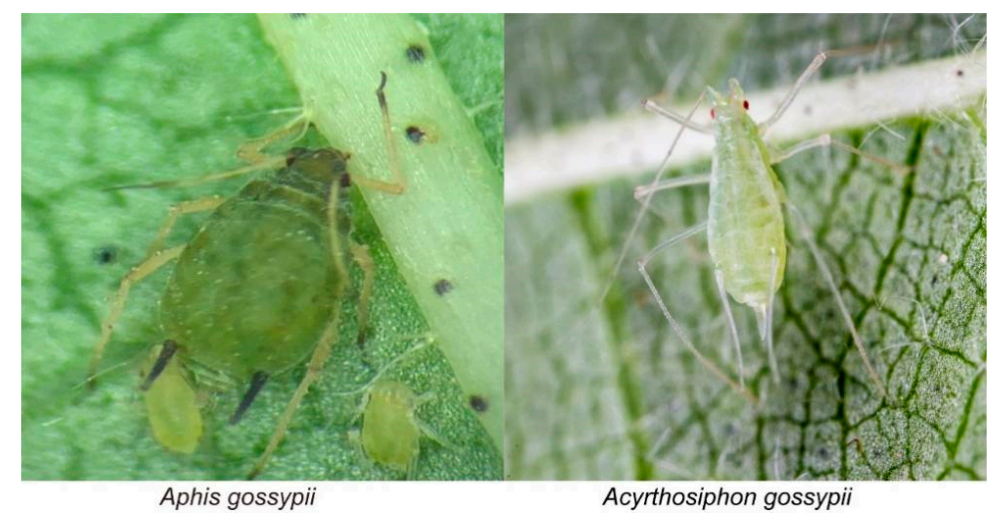

Figure 1. Adult of Aphis gossypii and Acyrthosiphon gossypii.

\subsection{Tested Temperatures}

The values of the tested temperatures were determined based on previous studies $[2,16,19,20]$ and our preliminary experiment. Here, we chose three temperatures: $29^{\circ} \mathrm{C}$ (optimal temperature, as control), $32{ }^{\circ} \mathrm{C}$ (moderately increased temperature), and $35^{\circ} \mathrm{C}$ (severely high temperature).

\subsection{Effects of Temperature on Survival and Fecundity of Adults}

Wild aphid population was reared in indoor chambers for one generation. One-dayold apterous adults from the first generation in indoor culture were randomly collected 
with a fine brush and transferred onto the lower surface of an excised leaf disk of cotton that was placed in small plastic box (diameter: $60 \mathrm{~mm}$, high: $50 \mathrm{~mm}$ ) on a layer of $1 \%$ agarose. To avoid aphid escape, the box was covered with 100 mesh gauze. Adults were allowed to produce progeny at $29^{\circ} \mathrm{C}$, and then transferred onto a new leaf disk after $24 \mathrm{~h}$. Newly produced nymphs were left in place and reared on their natal leaf. These nymphs were subsequently transferred onto new cotton leaf disks every 2-3 days. When nymphs had molted four times and developed to the adult stage, a group of 100 one-day-old adults $(<12 \mathrm{~h}$ old) were selected randomly and placed in chambers under a constant temperature $\left(29^{\circ} \mathrm{C}, 32^{\circ} \mathrm{C}\right.$, or $\left.35^{\circ} \mathrm{C}\right)$, with $50 \pm 5 \% \mathrm{RH}$, and $16: 8(\mathrm{~L} / \mathrm{D}) \mathrm{h}$ photoperiod. Ten adults were placed in each test plastic box (as mentioned above); so each temperature treatment had ten boxes. A group of ten adults constituted one. Adults were checked daily to record their survival and count the newly produced nymphs, which were removed daily. The aphid adults were transferred onto new cotton leaf disks every 1-2 days. Observations continued until all adults died.

\subsection{Electrical Recording of Aphid Feeding-Behaviors}

A Giga-8 direct current electrical penetration graph (DC-EPG) amplifier system with a 1 Giga $\Omega$ input resistance and an input bias current $<1 \mathrm{pA}$ in a Faraday cage (manufactured by Wageningen University, Wageningen, The Netherlands) was used to record the feeding behaviors of aphid adults on cotton in this experiment [38]. The structural design of this system is shown in Supplementary Figure S1. Newly emerged apterous adult aphids $(<12 \mathrm{~h}$ old $)$, reared on cotton leaf at $29^{\circ} \mathrm{C}$, were randomly selected and were subjected to a $1 \mathrm{~h}$ starvation period before recording their behaviors at the control temperature condition. A gold wire (12.5 $\mu \mathrm{m}$ in dia, $2 \mathrm{~cm}$ long) was attached on the dorsum of the aphid with water soluble conductive silver glue. The gold wire was glued to copper wire $(2 \mathrm{~mm}$ dia $\times 2 \mathrm{~cm}$ length) attached to a brass pin that was inserted into the EPG probe as the insect electrode. The aphids, which were glued to gold wire, were transferred into the tested room at a fixed temperature condition that had been set in advance $\left(29^{\circ} \mathrm{C}, 32^{\circ} \mathrm{C}, 35^{\circ} \mathrm{C}\right)$. The cotton plants grown at the control temperature condition $\left(28-30^{\circ} \mathrm{C}\right)$ were simultaneously transferred into the tested room. The temperature was checked every two hours to maintain the fixed temperature during the whole experiment. A copper wire $(2 \mathrm{~mm}$ dia $\times 10 \mathrm{~cm}$ length $)$ was inserted into the soil of the pot as the plant electrode. As the aphid's stylets penetrated the plant, the circuit was completed, and a fluctuating voltage was amplified with the Giga-8 DC amplifier between $\pm 5 \mathrm{~V}$ at the amplifier output, and recordings were made on Stylet $+\mathrm{d}$ software. The EPG device, in an electrically grounded Faraday cage, was placed in a quiet room to avoid external noise. Aphids were gently placed onto the lower surface of a single cotton leave (on a plant at four-leaf stage) and this test leaf was tied to a stick to hold it steady. Using an eight-channel amplifier, we simultaneously recorded eight individual aphids on separate plants for $8 \mathrm{~h}$. The two species, Ap. gossypii and Ac. gossypii, were recorded simultaneously and each species was randomly assigned to four of the available channels. New cotton plants and new aphids were used for each recording session. The EPG analysis was based on data collected from more than 18 aphids for each treatment (species $\times$ temperature). The EPG data were annotated using the Stylet + a software (Wageningen Agricultural University, Wageningen, The Netherlands). Waveform patterns were scored and assigned to previously described categories [38]: (1) non penetration (NP), representing non-probing behavior where the stylets are not in contact with the leaf surface; (2) initiation of stylet penetration of leaf tissue (which correlates with the intercellular apoplastic stylet pathway located at the epidermis/mesophyll cell layers in which the aphid shows a cyclic activity of mechanical stylet penetration and secretion saliva (C)); (3) short bouts of intracellular penetration, which leads to a signal potential drop (Pd); (4) secretion of saliva into phloem sieve elements at the beginning of the phloem phase (E1); (5) passive phloem sap uptake from the sieve element, i.e., phloem ingestion (E2); (6) ingestion of xylem sap (G); and (7) period of mechanical difficulty in stylet penetration (F). 


\subsection{Statistical Analysis}

Statistical analysis was performed with Microsoft Excel (Microsoft, Redmond, WA, USA) and SPSS v.20.0 software (IBM Corporation, Armonk, NY, USA). All data were first checked for normality and homogeneity of variance and were transformed when they did not fit a normal distribution. The results from two independent groups were compared using a Student's $t$-test. One-way analyses of variance (ANOVAs) were performed to determine the effects of temperature on feeding behavior, and the Bonferroni method was used to adjust the $p$-values, which were considered statistically significant between temperature treatments at $p<0.05$. Survival statistics was calculated using the Kaplan-Meier survival curve and compared using the log-rank test. Graphs were made by GraphPad Prism 8.0 (GraphPad Software, La Jolla, CA, USA). If not otherwise stated, statistical significance was indicated as follows: ${ }^{*}, p<0.05 ;{ }^{* *}, p<0.01 ;{ }^{* * *}, p<0.001$.

\section{Results}

\subsection{Survival, Longevity, and Fecundity}

The survival rates of Ap. gossypii and Ac. gossypii were each significantly affected by high temperatures (Figure 2a-c. a: $p<0.0001 ; \mathrm{b}: p<0.0001$; $\mathrm{c}: p<0.0001$ ). Both aphid species died sooner at $35{ }^{\circ} \mathrm{C}$ than at $29^{\circ} \mathrm{C}$ (Figure 2a,c). At $35{ }^{\circ} \mathrm{C}$, all Ac. gossypii died by day 7 , while $57 \%$ of $A p$. gossypii were still alive. At $32{ }^{\circ} \mathrm{C}$, all Ac. gossypii died within 12 days, while $49 \%$ of Ap. gossypii survived $>12$ days (Figure $2 b$ ).
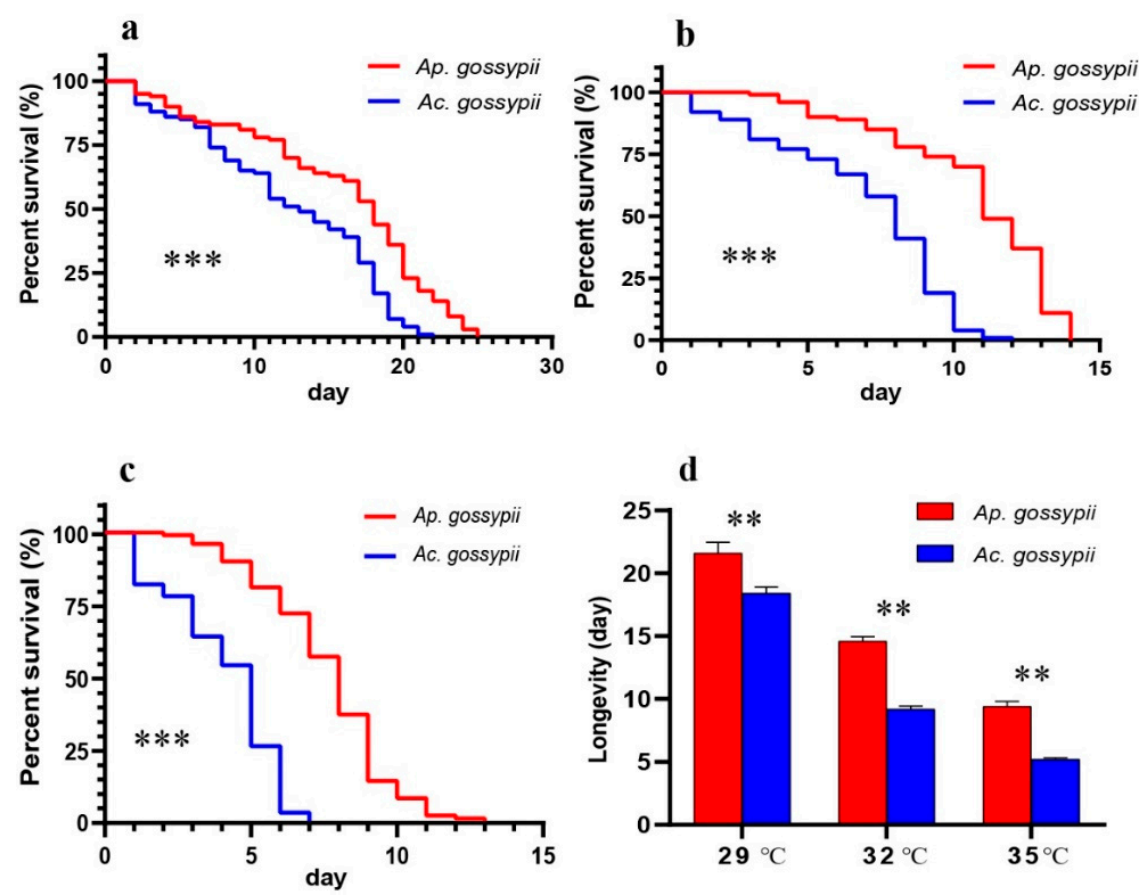

Figure 2. Survival curves of adults of Aphis gossypii and Acyrthosiphon gossypii at three temperatures: (a) $29{ }^{\circ} \mathrm{C}$; (b) $32{ }^{\circ} \mathrm{C}$; (c) $35^{\circ} \mathrm{C}$; and (d) longevity of adults of both species. Survival statistics were calculated using the Kaplan-Meier survival curve and compared using the log-rank test (individual $=100$ ). The results from two independent groups of longevity were assessed using Student's $t$-test. The error bars indicate standard error (SE). ${ }^{* *}$, $p<0.01 ; * * *, p<0.001$.

In general, the longevity of Ac. gossypii was reduced to a greater extent by high temperatures than the longevity of Ap. gossypii (Figure 2d). For example, an increase from 29 to $35{ }^{\circ} \mathrm{C}$ caused the longevity of Ac. gossypii to drop by $72 \%$, while that of Ap. gossypii declined only $53 \%$.

Age-specific fecundity of both aphids was reduced by high temperatures (Figure 3a-c), but this occurred at a lower temperature and more severely for Ac. gossypii. Using the 
maximum age-specific daily fecundity to express this effect, for the more tolerant species (Ap. gossypii), fecundity dropped from 8.01 to 4.34 to 2.99 as temperatures rose from 29 to 32 to $35^{\circ} \mathrm{C}$, and the peak of oviposition shifted from day 5 at the lowest temperature to day 1 at the two higher temperatures. For Ac. gossypii, daily fecundity was much lower that for the other aphid species at all temperatures, but daily maximum fecundity for this second species showed the same pattern of reduction, from 2.46 to 2.19 to 0.38 for 29, 32, and $35^{\circ} \mathrm{C}$, respectively, with these peaks being on day 1 for all temperatures.
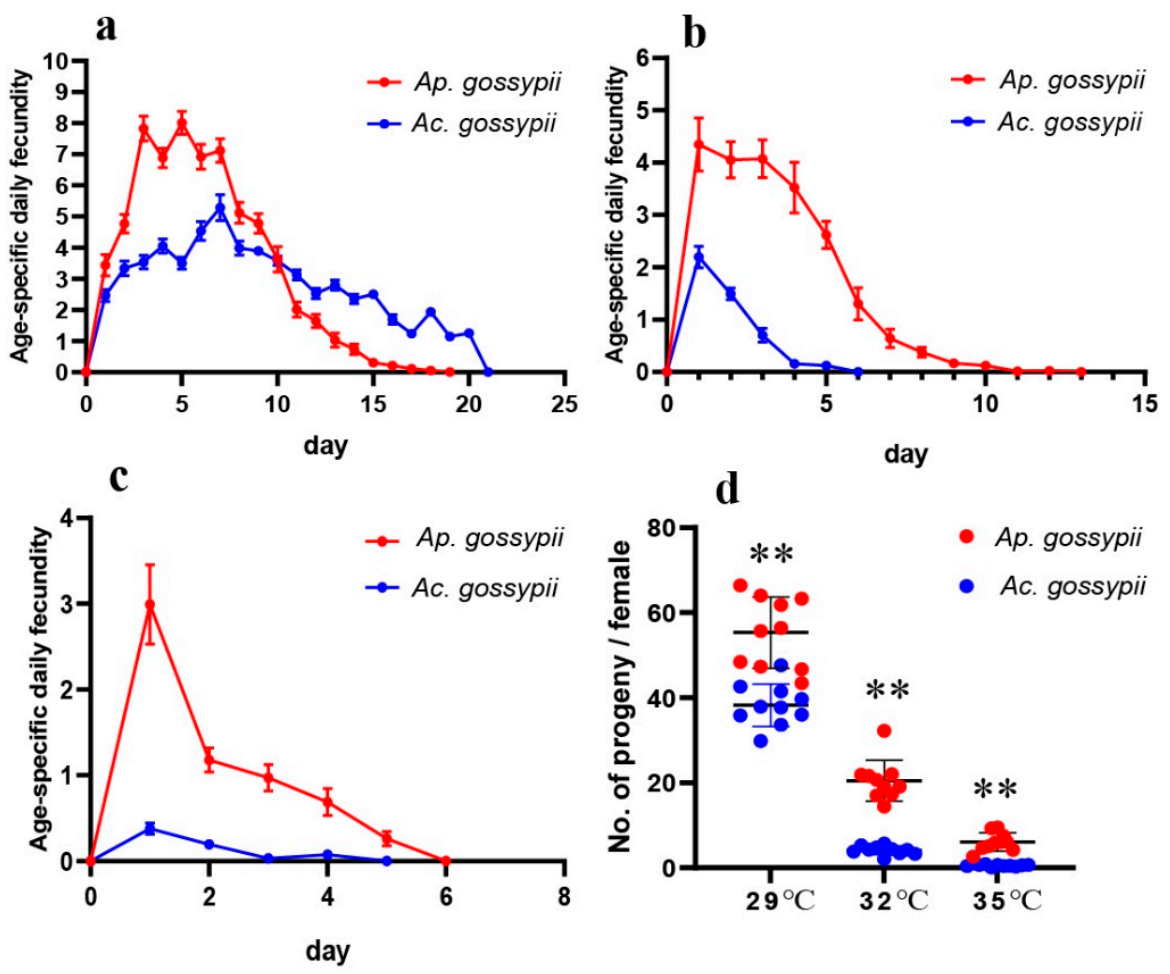

Figure 3. Age-stage-specific fecundity of adults of Aphis gossypii and Acyrthosiphon gossypii at different temperatures. (a) $29^{\circ} \mathrm{C}$; (b) $32{ }^{\circ} \mathrm{C}$; (c) $35^{\circ} \mathrm{C}$; and (d) the scatter diagram of progeny per female. The results from two independent groups of fecundity were assessed using Student's $t$-test. The error bars indicate standard error (SE). ${ }^{* *}, p<0.01$.

\subsection{Feeding Behavior}

Data on the non-phloem phase variables of Ap. gossypii and Ac. gossypii at different temperatures (Table 1) show that the duration of non-probe $(\mathrm{Np})$ events such as walking and resting for Ap. gossypii was significantly longer at $35{ }^{\circ} \mathrm{C}$ than at $29{ }^{\circ} \mathrm{C}(p<0.001)$ and $32{ }^{\circ} \mathrm{C}(p<0.001)$. However, the time spent in $\mathrm{Np}$ (non-probing/penetration) by Ac. gossypii was significantly higher than for Ap. gossypii at all temperatures $\left(29^{\circ} \mathrm{C}: p<0.001\right.$; $32{ }^{\circ} \mathrm{C}: p<0.001 ; 35^{\circ} \mathrm{C}: p<0.001 ; t$-test); moreover, the time of the np phase of Ac. gossypii increased with rising temperatures. The percentage of non-probing behaviors of the total recording $\left(8 \mathrm{~h}\right.$ ) was $2.71 \%, 2.28 \%$, and $7.03 \%$ at $29^{\circ} \mathrm{C}, 32{ }^{\circ} \mathrm{C}$, and $35^{\circ} \mathrm{C}$ for Ap. gossypii, respectively, which was lower than for Ac. gossypii $\left(29{ }^{\circ} \mathrm{C}: 17.89 \%\right.$; $32{ }^{\circ} \mathrm{C}: 29.12 \% ; 35^{\circ} \mathrm{C}$ : $39.15 \%$ ) (Figure 4). The intercellular stylet pathways (C) time was lower at $32{ }^{\circ} \mathrm{C}$ for $\mathrm{Ap}$. gossypii compared with the other two temperatures. However, no significant differences were observed in the duration of the $C$ waves $(p=0.096)$ and potential drops $(\mathrm{Pd})(p=0.055)$ of Ac. gossypii between the three temperatures. No significant differences were observed in the duration of short potential drops (Pd) $(p=0.109)$ or times spent feeding on xylem (G) $(p=0.942)$ for Ap. gossypii at all temperatures. However, the number of intercellular stylet pathways event $(\mathrm{C})$ and potential drops $(\mathrm{Pd})$ at $35^{\circ} \mathrm{C}$ was significantly higher for $A p$. gossypii than the other two temperatures. These results show that the number $(p=0.043)$ of potential drops (Pd) for Ac. gossypii at $35^{\circ} \mathrm{C}$ was significantly lower than at $29{ }^{\circ} \mathrm{C}$. The 
duration of xylem feeding events (G) for Ac. gossypii at $35^{\circ} \mathrm{C}$ was significantly lower than at $29^{\circ} \mathrm{C}(p=0.039)$.

\section{Ap. gossypii}

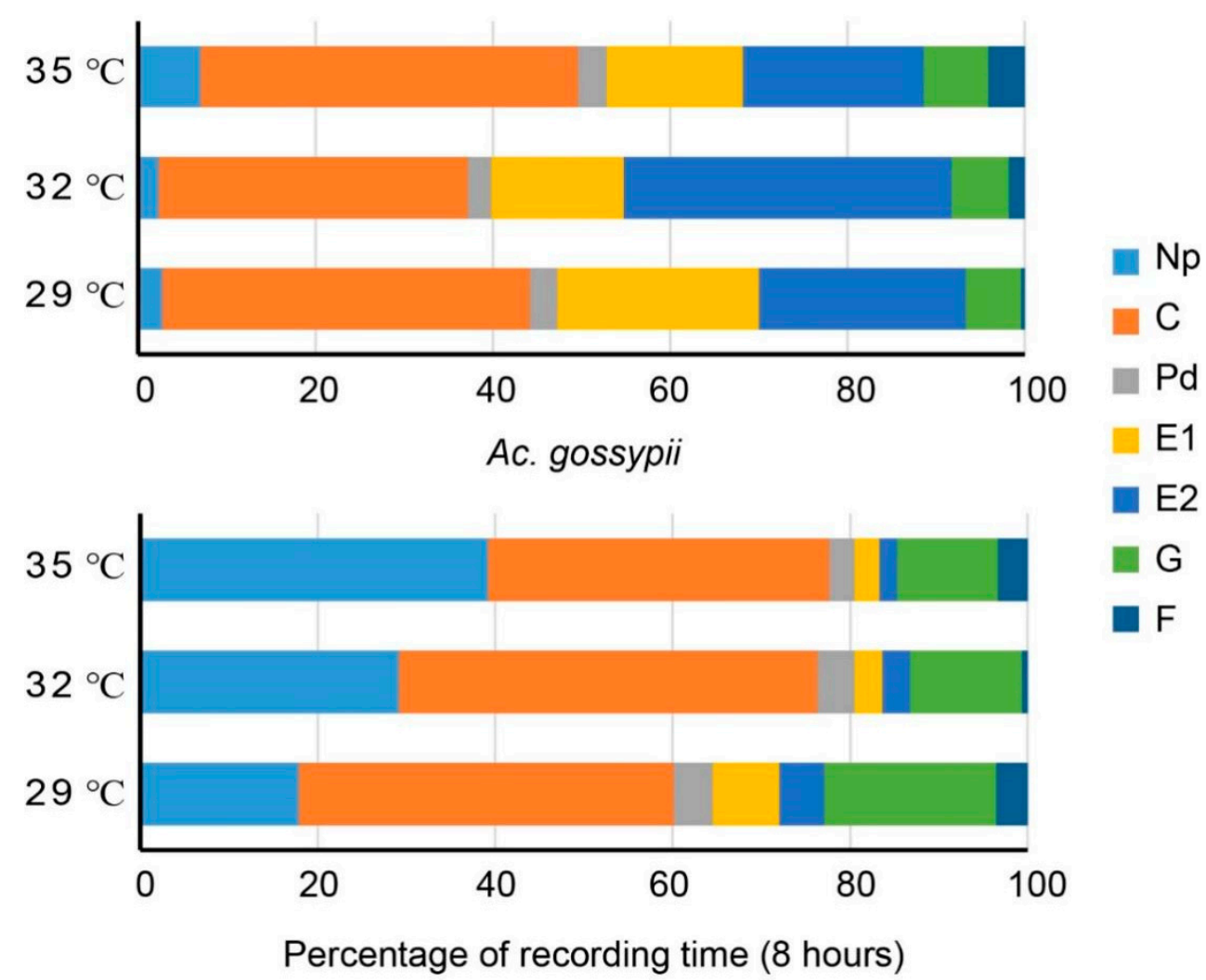

Figure 4. Proportional duration of various waveforms of Aphis gossypii and Acyrthosiphon gossypii behavior at different temperatures during an $8 \mathrm{~h}$ EPG recording. EPG waveforms are as $\mathrm{Np}=$ nonprobing/penetration; $\mathrm{C}$ = pathway waveform; $\mathrm{Pd}=$ potential drop; $\mathrm{E} 1$ = salivary secretion; $\mathrm{E} 2$ : phloem sap ingestion; $\mathrm{G}=$ xylem feeding; $\mathrm{F}=$ mechanical penetration difficulties.

For the phloem-feeding phase variables (Table 2), there were significant differences between Ap. gossypii and Ac. gossypii. Specifically, Ap. gossypii at $32{ }^{\circ} \mathrm{C}(p=0.029)$ and $35^{\circ} \mathrm{C}(p=0.021)$ spent significantly less time on phloem salivation (E1) compared with at $29^{\circ} \mathrm{C}$. However, the phloem ingestion (E2) time of Ap. gossypii at $32{ }^{\circ} \mathrm{C}$ was longer than at the other two temperatures, which accounts for $37.0 \%$ of recorded time, which was higher than at $29^{\circ} \mathrm{C}(23.4 \%)$ or $35^{\circ} \mathrm{C}(20.4 \%)$ (Figure 4$)$. The duration of salivary secretion events (E1) of Ac. gossypii at $29^{\circ} \mathrm{C}$ was significantly higher than at $32{ }^{\circ} \mathrm{C}(p=0.004)$ and $35^{\circ} \mathrm{C}$ $(p=0.003)$. Temperature had no impact on the number of E1 or E2 events for Ap. gossypii. However, for Ac. gossypii, the numbers of E1 and E2 events were significantly affected by $35^{\circ} \mathrm{C}$ compared with $29^{\circ} \mathrm{C}$. No significance was observed in the times for first salivary secretion (E1) $(p=0.551)$ or first established phloem feeding (E2) ( $p=0.295)$ for Ap. gossypii among the three temperatures. 
Table 1. Comparison of electrical penetration graph (EPG) parameters of Aphis gossypii and Acyrthosiphon gossypii in the non-phloem phase under different temperatures.

\begin{tabular}{|c|c|c|c|c|c|c|}
\hline \multirow{2}{*}{ EPG Parameters } & \multicolumn{3}{|c|}{ Aphis gossypii } & \multicolumn{3}{|c|}{ Acrythosiphon gossypii } \\
\hline & $29^{\circ} \mathrm{C}(n=18)$ & $32{ }^{\circ} \mathrm{C}(n=18)$ & $35^{\circ} \mathrm{C}(n=26)$ & $29^{\circ} \mathrm{C}(n=19)$ & $32{ }^{\circ} \mathrm{C}(n=18)$ & $35^{\circ} \mathrm{C}(n=20)$ \\
\hline Total duration of $\mathrm{Np}$ (min) & $13.00 \pm 1.56 \mathrm{bB}$ & $10.97 \pm 1.27 \mathrm{bB}$ & $33.77 \pm 2.32 \mathrm{aB}$ & $85.88 \pm 7.49 \mathrm{cA}$ & $139.80 \pm 10.45 \mathrm{bA}$ & $187.92 \pm 14.34 \mathrm{aA}$ \\
\hline Total duration of C (min) & $199.26 \pm 9.96 \mathrm{aA}$ & $167.49 \pm 8.56 \mathrm{bB}$ & $204.41 \pm 10.55 \mathrm{aA}$ & $202.64 \pm 13.34 \mathrm{aA}$ & $226.70 \pm 15.01 \mathrm{aA}$ & $184.69 \pm 12.55 \mathrm{aA}$ \\
\hline Total duration of Pd (min) & $14.75 \pm 0.82 \mathrm{aB}$ & $12.78 \pm 0.89 \mathrm{aB}$ & $15.74 \pm 0.96 \mathrm{aA}$ & $21.15 \pm 2.40 \mathrm{aA}$ & $20.06 \pm 1.89 \mathrm{aA}$ & $14.05 \pm 1.69 \mathrm{aA}$ \\
\hline Total number of $\mathrm{C}$ & $251 \pm 11.37 \mathrm{bB}$ & $225.20 \pm 11.81 \mathrm{bB}$ & $307.78 \pm 14.15 \mathrm{aB}$ & $329.93 \pm 20.50 \mathrm{aA}$ & $293.29 \pm 15.15 \mathrm{abA}$ & $242.85 \pm 13.24 \mathrm{bA}$ \\
\hline Total number of pd & $158 \pm 10.52 \mathrm{bB}$ & $145 \pm 11.79 \mathrm{bB}$ & $202 \pm 12.71 \mathrm{aB}$ & $230.4 \pm 16.7 \mathrm{aA}$ & $258.2 \pm 18.6 \mathrm{aA}$ & $169.92 \pm 14.38 \mathrm{bA}$ \\
\hline Total duration of $\mathrm{G}$ & $30.1 \pm 4.56 \mathrm{aB}$ & $31.05 \pm 5.18 \mathrm{aB}$ & $34.97 \pm 5.77 \mathrm{aB}$ & $93.07 \pm 10.16 \mathrm{aA}$ & $60.62 \pm 7.87 \mathrm{abA}$ & $54.58 \pm 8.06 \mathrm{bA}$ \\
\hline
\end{tabular}

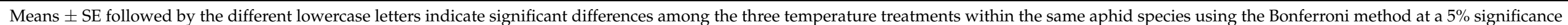

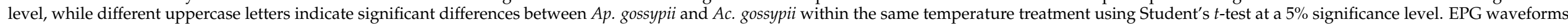
are $\mathrm{Np}=$ non-probing/penetration; $\mathrm{C}=$ pathway waveform; $\mathrm{Pd}=$ potential drop; $\mathrm{G}=$ xylem feeding. The numbers in parentheses are the numbers of aphids tested at each temperature treatment.

Table 2. Comparison of EPG parameters of Aphis gossypii and Acyrthosiphon gossypii in the phloem phase under different temperatures.

\begin{tabular}{|c|c|c|c|c|c|c|}
\hline \multirow{2}{*}{ EPG Parameters } & \multicolumn{3}{|c|}{ Aphis gossypii } & \multicolumn{3}{|c|}{ Acyrthosiphon gossypii } \\
\hline & $29^{\circ} \mathrm{C}(n=18)$ & $32{ }^{\circ} \mathrm{C}(n=18)$ & $35^{\circ} \mathrm{C}(n=26)$ & $29^{\circ} \mathrm{C}(n=19)$ & $32{ }^{\circ} \mathrm{C}(n=18)$ & $35^{\circ} \mathrm{C}(n=20)$ \\
\hline Total duration of E1 (min) & $108.83 \pm 10.78 \mathrm{aA}$ & $71.71 \pm 8.49 \mathrm{bA}$ & $73.65 \pm 7.97 \mathrm{bA}$ & $36.10 \pm 5.10 \mathrm{aB}$ & $14.78 \pm 1.75 \mathrm{bB}$ & $13.36 \pm 1.17 \mathrm{bB}$ \\
\hline Total duration of E2 (min) & $112.28 \pm 14.34 \mathrm{bA}$ & $177.49 \pm 14.25 \mathrm{aA}$ & $97.70 \pm 8.47 \mathrm{bA}$ & $24.17 \pm 1.69 \mathrm{aB}$ & $15.06 \pm 1.71 \mathrm{bB}$ & $9.37 \pm 1.01 \mathrm{cB}$ \\
\hline Percentage of E1 + E2 & $0.461 \pm 0.037 \mathrm{aA}$ & $0.519 \pm 0.032 \mathrm{aA}$ & $0.357 \pm 0.023 \mathrm{bA}$ & $0.125 \pm 0.011 \mathrm{aB}$ & $0.062 \pm 0.006 \mathrm{bB}$ & $0.047 \pm 0.003 \mathrm{bB}$ \\
\hline Total number of single E1 & $4.58 \pm 0.39 \mathrm{abB}$ & $3.42 \pm 0.55 \mathrm{aB}$ & $5.22 \pm 0.85 \mathrm{aA}$ & $6.61 \pm 1.01 \mathrm{aA}$ & $6.45 \pm 0.86 \mathrm{aA}$ & $5.92 \pm 0.63 \mathrm{aA}$ \\
\hline Total number of E1 & $24.62 \pm 2.17 \mathrm{aA}$ & $21.73 \pm 2.14 \mathrm{aA}$ & $24.07 \pm 2.43 \mathrm{aA}$ & $13.12 \pm 1.37 \mathrm{aB}$ & $10.70 \pm 1.15 \mathrm{abB}$ & $7.92 \pm 0.92 \mathrm{bB}$ \\
\hline Total number of E2 & $13.61 \pm 1.85 \mathrm{aA}$ & $12.46 \pm 1.68 \mathrm{aA}$ & $12.69 \pm 1.75 \mathrm{aA}$ & $4.54 \pm 0.53 \mathrm{aB}$ & $3.17 \pm 0.36 \mathrm{abB}$ & $2.50 \pm 0.42 \mathrm{bB}$ \\
\hline Time to first E1 (min) & $64.12 \pm 13.82 \mathrm{aB}$ & $67.23 \pm 16.02 \mathrm{aB}$ & $49.08 \pm 8.68 \mathrm{aB}$ & $93.27 \pm 16.12 \mathrm{aA}$ & $109.20 \pm 14.2 \mathrm{aA}$ & $90.38 \pm 12.2 \mathrm{aA}$ \\
\hline $\begin{array}{l}\text { Sustain phloem ingestion } \\
\qquad(\mathrm{E} 2>10 \mathrm{~min})\end{array}$ & $2.93 \pm 0.32 \mathrm{a}$ & $3.08 \pm 0.40 \mathrm{a}$ & $2.52 \pm 0.26 \mathrm{a}$ & - & - & - \\
\hline
\end{tabular}

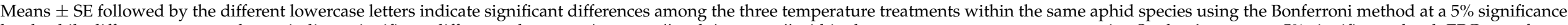

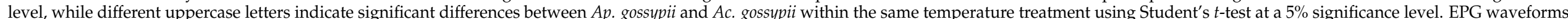

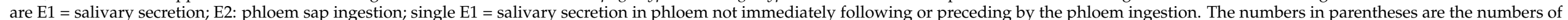
each temperature treatment. 


\section{Discussion}

This is the first study to investigate the feeding behavior of Ap. gossypii and Ac. gossypii adults, at different temperatures, using the electrical penetration graph (EPG) technique. Moreover, the effects of high temperatures on the survival rates and fecundity of adults for these two co-existing cotton aphids were determined.

There were no deaths for Ap. gossypii within the first $24 \mathrm{~h}$ under any of the temperatures examined. However, no deaths during the first $24 \mathrm{~h}$ for Ac. gossypii were observed at $29^{\circ} \mathrm{C}$, and the species' survival rate decreased faster than that of Ap. gossypii with the increase of treatment time. Heat stress can also modify the age-specific daily fecundity of Ap. gossypii and Ac. gossypii. The number of offspring produced by one adult of Ap. gossypii was 4.35 at $32{ }^{\circ} \mathrm{C}$ in the first $24 \mathrm{~h}$, which was higher than the value for this aphid when held at $29^{\circ} \mathrm{C}$ (3.44) or $35^{\circ} \mathrm{C}(2.99)$. However, the fecundity of Ac. gossypii within $24 \mathrm{~h}$ showed differences between $29^{\circ} \mathrm{C}$ and $32^{\circ} \mathrm{C}$. The age-specific daily fecundity values for both Ap. gossypii and Ac. gossypii at $32{ }^{\circ} \mathrm{C}$ and $35^{\circ} \mathrm{C}$ decreased continuously over time after day one, which contrasts results from $29^{\circ} \mathrm{C}$. Overall, the fecundity of these two aphids was eventually impaired as the time under heat stress increased. These results indicated that heat stress had a greater negative effect on the survival rate and the fecundity of $A c$. gossypii than it did on that of Ap. gossypii, which is consistent with previous studies [16,20].

Our results also found that Ac. gossypii spent more time feeding on xylem than on phloem under all temperatures, which contrasted with the behavior of Ap. gossypii, possibly for two reasons. First, it is possible that these two aphids simply have different feeding strategies. It may be that Ac. gossypii needs more water and inorganic salt than Ap. gossypii, with a feeding pattern more similar to three grain aphids (S. avenae, Sitobion graminum (Rondani), and Rhopalosiphum padi (Linnaeus)) [39]. Rhopalosiphum padi spends more time feeding on xylem than the other two grain aphid species. Xylem consumption helps aphids cope with the osmotic effects associated with phloem feeding [40]. Moreover, aphids engage in more xylem feeding than phloem feeding if the plant is unacceptable [41]. The increase in xylem feeding by Ac. gossypii may have been to compensate for its reduced ingestion of phloem, which would be consistent with the observation that starved aphids also increase their time spent in xylem feeding [42,43]. The time of xylem feeding for Ac. gossypii significantly decreased at $35^{\circ} \mathrm{C}$, in contrast with Ap. gossypii, which indicates that the severe high temperatures have adverse effects on xylem feeding for Ac. gossypii.

For aphids to successfully feed on phloem sieve elements, the aphids need to secrete saliva (E1 behavior) containing $\mathrm{Ca}^{2+}$-scavenging proteins that help prevent phloem proteins from clogging inside sieve elements. During actual phloem feeding (E2 behavior), further saliva is added to the ingested sap, likely to prevent phloem proteins from clogging inside the capillary food canal of the aphid [42,44,45]. With the aid of these saliva-based factors, aphids can ingest phloem sap continuously for extended periods. Aphis gossypii fed on resistant melon plants showed longer phloem salivation periods and no sustained ( $>10 \mathrm{~min}$ ) periods of phloem feeding, in contrast with feeding behavior on susceptible melon plants [46]. Acyrthosiphon pisum spent less time in E2 ingestion on a non-preferred host plant before acclimation when compared with a preferred host plant [47]. In the present study, a significantly lower time of E2 ingestion for Ap. gossypii reared on cotton plant at $35^{\circ} \mathrm{C}$ compared with $32{ }^{\circ} \mathrm{C}$ indicated that $A p$. gossypii is unable to sustain phloem feeding for a long time when exposed to severe high temperatures $\left(35^{\circ} \mathrm{C}\right)$. Extrapolating from the time spent by Ac. gossypii in our study on Np phase activities, we found that, at $35^{\circ} \mathrm{C}$, aphids needed less time to insert their stylets into the plant tissue. Moreover, we observed no sustained period of phloem ingestion (E2 > $10 \mathrm{~min}$ ) for Ac. gossypii at any of the tested temperatures (Table 2), which suggests that Ac. gossypii was not able to sustain phloem ingestion. Data for phloem ingestion levels showed that moderate heat stress $\left(32{ }^{\circ} \mathrm{C}\right)$ can improve feeding efficiency of $\mathrm{Ap}$. gossypii, but the beneficial effects of increased temperature were limited to a range of just a few degrees and became negative above Ap. gossypii's heat tolerance level $\left(35^{\circ} \mathrm{C}\right)$. In contrast, for Ac. gossypii, both 32 and $35^{\circ} \mathrm{C}$ had adverse effects on phloem-feeding-related activities. This difference shows that 
the feeding behavior of Ac. gossypii is more sensitive to increasing temperature than adults of Ap. gossypii.

Phloem sap provides aphids with nutrients such as amino acids and sugar resources, which are needed for growth and reproduction $[48,49]$. In alfalfa, phloem amino acid balance affects plant resistance, which can affect $A$. pisum reproduction [50]. Pompon et al. [40] reported that the number of nymphs produced by Macrosiphum euphorbiae (Thomas) was negatively correlated with the proportion of time spent in xylem feeding. The lack of phloem feeding may be one of the reasons for the severely reduced fecundity of Ac. gossypii under heat stress. However, a high temperature can affect the survival rate and fecundity of insects by changing their physiological metabolic rates and modifying the spatial conformation of protein [51,52], which is a very complex process. Furthermore, different insect species show different thermal tolerances, and thus have different levels of fitness $[53,54]$. Previous studies reported that aphid's intracellular Buchnera and facultative symbiont such as Serratia symbiotica play a crucial role in thermal tolerance of aphids [54,55]. Aphid's facultative symbiont can affect aphid feeding behavior. For example, Rhopalosiphum padi infected with facultative symbiont, Hamiltonella defensa, reared on barley exhibited a twofold higher probability of sustained phloem ingestion than uninfected aphids [56]. Future study is needed to determine the shifts in obligatory, and facultative endosymbiont infections of $A p$. gossypii and Ac. gossypii to explain why the fitness of these aphids was reduced under heat stress. A recent study showed that heat shock genes are involved in protein interaction and as function molecular chaperones to improve aphid heat tolerance [57]. The expression of HSP83 for A. pisum was reduced by RNA interference and, consequently, both the longevity and fecundity of the aphid were reduced [58]. In our study, the EPG technique was used to help us to understand the differential effects of high temperatures on probing and feeding activities of Ap. gossypii and Ac. gossypii. However, future work is needed to consider the role of phloem sap chemical composition relative to insect resistance, salivary proteins, endosymbionts, and Hsp genes to help determine the underlying mechanisms and gain a better understanding of how we can reduce thermal tolerance in pest aphids under a future warmer climate.

\section{Conclusions}

In the present study, we examined the effects of different temperatures $(29,32$, and $35^{\circ} \mathrm{C}$ ) on adult survival, fecundity, and feeding behavior of two cotton-feeding aphid species. Our results show that the adverse effects of high temperatures on adult survival rate and fecundity were greater for Ac. gossypii than Ap. gossypii. The feeding data we collected showed that Ac. gossypii spent more feeding on xylem than phloem under all temperature treatments, which contrasted with Ap. gossypii. Moreover, xylem feeding of Ap. gossypii was not affected by heat stress. However, for Ac. gossypii, heat stress had adverse effects on both phloem ingestion and xylem feeding. Data generated in this study will serve as the basis for predicting the effects of increased temperatures on these two cotton aphids.

Supplementary Materials: The following are available online at https:/ /www.mdpi.com/article/10 .3390 /insects12060565/s1. Figure S1: A direct current electrical penetration graph amplifier system with Faraday cage.

Author Contributions: Y.L.: conceived and designed the research. J.L. and C.W.: conducted the experiments. J.L. and C.W.: collected the data. J.L., N.D., and Y.L.: analyzed the data. J.L., N.D., and Y.L.: wrote the manuscript. J.L., N.D., and Y.L.: reviewed and edited the manuscript. All authors wrote and reviewed the manuscript. All authors have read and agreed to the published version of the manuscript.

Funding: This work was supported by the National Natural Science Funds of China (U2003212), and China Agriculture Research System (CARS-15-19).

Institutional Review Board Statement: Not applicable. 
Informed Consent Statement: Not applicable.

Data Availability Statement: All data analyzed in this study are included in this article.

Conflicts of Interest: The authors declare no conflict of interest.

\section{References}

1. Jamieson, M.A.; Trowbridge, A.M.; Raffa, K.F.; Lindroth, R.L. Consequences of climate warming and altered precipitation patterns for plant-insect and multitrophic interactions. Plant Physiol. 2012, 160, 1719-1727. [CrossRef] [PubMed]

2. IPCC. Climate Change 2014: Synthesis Report. Contribution of Working Groups I, II and III to the Fifth Assessment Report of the Intergovernmental Panel on Climate Change; Core Writing Team, Pachauri, R.K., Meyer, L.A., Eds.; IPCC: Geneva, Switzerland, 2014; p. 151.

3. Bale, J.; Masters, G.J.; Hodkinson, I.; Awmack, C.; Bezemer, T.M.; Brown, V.; Butterfield, J.; Buse, A.; Coulson, J.C.; Farrar, J.; et al. Herbivory in global climate change research: Direct effects of rising temperature on insect herbivores. Glob. Chang. Biol. 2002, 8, 1-16. [CrossRef]

4. Wang, S.S.; Chen, X.; Li, Y.; Pan, B.Y.; Wang, S.G.; Dai, H.J.; Wang, S.; Tang, B. Effects of changing temperature on the physiological and biochemical properties of Harmonia axyridis larvae. Entomol. Gen. 2020, 40, 229-241. [CrossRef]

5. Yao, F.L.; Ding, X.L.; Mei, W.J.; Zheng, Y.; Desneux, N.; He, Y.X.; Weng, Q.Y. Impact of heat stress on the development of egg and adult coccinellid Serangium japonicum: Evidence for cross-stage and cross-generation effects. Entomol. Gen. 2020, 40, 365-376. [CrossRef]

6. Ma, G.; Ma, C.S. Climate warming may increase aphids' dropping probabilities in response to high temperatures. J. Insect Physiol. 2012, 58, 1456-1462. [CrossRef] [PubMed]

7. Ma, G.; Ma, C.S. Effect of acclimation on heat-escape temperatures of two aphid species: Implications for estimating behavioral response of insects to climate warming. J. Insect Physiol. 2012, 58, 303-309. [CrossRef]

8. Bussaman, P.; Sa-uth, C.; Chandrapatya, A.; Atlihan, R.; Gökce, A.; Saska, P.; Chi, H. Fast population growth in physogastry reproduction of Luciaphorus perniciosus (Acari: Pygmephoridae) at different temperatures. J. Econ. Entomol. 2017, 110, 1397-1403. [CrossRef]

9. Guo, J.Y.; Lin, C.; Wan, F.H. Multiple generation effects of high temperature on the development and fecundity of Bemisia tabaci (Gennadius) (Hemiptera: Aleyrodidae) biotype B. Insect Sci. 2013, 20, 541-549. [CrossRef]

10. Bale, J.S.; Hayward, S.A.L. Insect overwintering in a changing climate. J. Exp. Biol. 2010, 213, 980. [CrossRef]

11. Zhao, F.; Zhang, W.; Hoffmann, A.A.; Ma, C.S. Night warming on hot days produces novel impacts on development, survival and reproduction in a small arthropod. J. Anim. Ecol. 2013, 83, 769-778. [CrossRef]

12. Wu, Y.; Li, J.; Liu, H.; Qiao, G.; Huang, X. Investigating the impact of climate warming on phenology of aphid pests in China using long-term historical data. Insects 2020, 11, 167. [CrossRef]

13. Lande, R. Adaptation to an extraordinary environment by evolution of phenotypic plasticity and genetic assimilation. J. Evol. Biol. 2009, 22, 1435-1446. [CrossRef]

14. Kuo, M.H.; Chiu, M.C.; Perng, J.J. Temperature effects on life history traits of the corn leaf aphid, Rhopalosiphum maidis (Homoptera: Aphididae) on corn in Taiwan. Appl. Entomol. Zool. 2006, 41, 171-177. [CrossRef]

15. Hullé, M.; Chaubet, B.; Turpeau, E.; Simon, J.C. Encyclop'Aphid: A website on aphids and their natural enemies. Entomol. Gen. 2020, 40, 97-101. [CrossRef]

16. Gao, G.Z.; Perkins, L.E.; Zalucki, M.P.; Lu, Z.Z.; Ma, J.H. Effect of temperature on the biology of Acyrthosiphon gossypii Mordvilko (Homoptera: Aphididae) on cotton. J. Pest. Sci. 2013, 86, 167-172. [CrossRef]

17. Gao, G.Z.; Lu, Z.Z.; Sun, P.; Xia, D.P. Effects of high temperature on the mortality and fecundity of two co-existing cotton aphid species Aphis gossypii Glover and Acyrthosiphon gossypii Mordvilko. Chin. J. Appl. Ecol. 2012, 23, 506-510.

18. Lv, Z.Z.; Tian, C.Y.; Song, Y.D. Relationship between Aphis gossypii and Acyrthosiphon gossypii on cotton in Xinjiang. China Cotton 2002, 29, 11-12.

19. Kersting, U.; Satar, S.; Uygun, N. Effect of temperature on development rate and fecundity of apterous Aphis gossypii Glover (Hom. Aphididae) reared on Gossypium hirsutum L. J. Appl. Entomol. 1999, 123, 23-27. [CrossRef]

20. Xia, J.Y.; Werf, W.V.D.; Rabbinge, R. Influence of temperature on bionomics of cotton aphid, Aphis gossypii, on cotton. Entomol. Exp. Appl. 2010, 90, 25-35. [CrossRef]

21. Satar, S.; Kersting, U.; Uygun, N. Effect of temperature on development and fecundity of Aphis gossypii Glover (Homoptera: Aphididae) on cucumber. J. Pest. Sci. 2005, 78, 133-137. [CrossRef]

22. Zamani, A.A.; Talebi, A.A.; Fathipour, Y.; Baniameri, V. Effect of temperature on biology and population growth parameters of Aphis gossypii Glover (Hom. Aphididae) on greenhouse cucumber. J. Appl. Entomol. 2010, 130, 453-460. [CrossRef]

23. Parajulee, M.N. Influence of constant temperatures on life history parameters of the cotton aphid, Aphis gossypii, infesting cotton. Environ. Entomol. 2007, 36, 666-672.

24. Ma, C.S.; Hau, B.; Poehling, H.M. The effect of heat stress on the survival of the rose grain aphid, Metopolophium dirhodum (Hemiptera: Aphididae). Eur. J. Entomol. 2004, 101, 327-331. [CrossRef]

25. Guo, H.; Sun, Y.C.; Peng, X.H.; Wang, Q.Y.; Marvin, H.; Ge, F. Up-regulation of abscisic acid signaling pathway facilitates aphid xylem absorption and osmoregulation under drought stress. J. Exp. Bot. 2016, 3, 681-693. [CrossRef] 
26. Sun, Y.; Guo, H.; Ge, F. Plant-aphid interactions under elevated $\mathrm{CO}_{2}$ : Some cues from aphid feeding behavior. Front. Plant Sci. 2016, 7, 502. [CrossRef] [PubMed]

27. Guo, H.; Peng, X.; Gu, L.; Wu, J.; Ge, F.; Sun, Y. Up-regulation of MPK4 increases the feeding efficiency of the green peach aphid under elevated $\mathrm{CO}_{2}$ in Nicotiana attenuata. J. Exp. Bot. 2017, 21-22, 5923-5935. [CrossRef]

28. Guo, H.J.; Zhang, Y.J.; Tong, J.H.; Hogenhout, S.A.; Ge, F.; Sun, Y.C. An aphid-secreted salivary protease activates plant defense in phloem. Curr. Biol. 2020, 30, 1-11. [CrossRef] [PubMed]

29. Jiang, S.; Liu, T.; Yu, F.; Teng, L.; Chen, F. Feeding behavioral response of cotton aphid, Aphis gossypii, to elevated CO 2 : EPG test with leaf microstructure and leaf chemistry. Entomol. Exp. Appl. 2016, 160, 219-228. [CrossRef]

30. James, C.K.; Perry, K.L. Transmission of plant viruses by aphid vectors. Mol. Plant. Pathol. 2004, 5, 505-511.

31. Munster, M.V. Impact of abiotic stresses on plant virus transmission by aphids. Viruses 2020, 12, 216. [CrossRef] [PubMed]

32. Tjallingii, W.F. Electronic recording of penetration behaviour by aphids. Entomol. Exp. Appl. 1978, 24, 521-530. [CrossRef]

33. Gabryś, B.; Pawluk, M. Acceptability of different species of brassicaceae as hosts for the cabbage aphid. Entomol. Exp. Appl. 2010, 91, 105-109. [CrossRef]

34. Tholt, G.; Samu, F.; Kiss, B. Feeding behaviour of a virus-vector leafhopper on host and non-host plants characterised by electrical penetration graphs. Entomol. Exp. Appl. 2015, 155, 123-136. [CrossRef]

35. Milenovic, M.; Wosula, E.N.; Rapisarda, C.; Legg, J.P. Impact of host plant species and whitefly species on feeding behavior of Bemisia tabaci. Front. Plant Sci. 2019, 10, 1. [CrossRef] [PubMed]

36. Jiang, Y.X.; Lei, H.; Collar, L.J.; Martin, B.; Muñiz, M.; Fereres, A. Probing and feeding behavior of two distinct biotypes of Bemisia tabaci (Homoptera: Aleyrodidae) on tomato plants. J. Econ. Entomol. 1999, 92, 357-366. [CrossRef]

37. Li, G.Y. Cotton Diseases and Pests in Xinjiang, 1st ed.; China Agricultural Press: Beijing, China, 2017; Volume 4, p. 168.

38. Tjallingii, W.F.; Esch, T.H. Fine structure of aphid stylet routes in plant tissues in correlation with EPG signals. Physiol. Entomol. 1993, 18, 317-328. [CrossRef]

39. Miao, J.; Wu, Y.; Yu, Z.; Yun, D.; Li, G. Comparative of feeding behaviors of Sitobion avenae, Sitobion graminum and Rhopalosiphum padi (Homoptera: Aphididae) using electrical penetration graph (EPG). Acta Ecol. Sin. 2011, 31, 175-182.

40. Pompon, J.; Dan, Q.; Giordanengo, P.; Pelletier, Y. Role of xylem consumption on osmoregulation in Macrosiphum euphorbiae (Thomas). J. Insect Physiol. 2010, 56, 610-615. [CrossRef] [PubMed]

41. Khan, S.A.; Marimuthu, M.; Predeesh, C.; Aguirre-Rojas, L.M.; Reese, J.C.; Smith, C.M. Electrical penetration graph recording of Russian wheat aphid (Hemiptera: Aphididae) feeding on aphid-resistant wheat and barley. J. Econ. Entomol. 2015, 108, 2465-2470. [CrossRef]

42. Kloth, K.J.; Busscher-Lange, J.; Wiegers, G.L.; Kruijer, W.; Buijs, G.; Meyer, R.C.; Albrectsen, B.R.; Bouwmeester, H.J.; Dicke, M.; Jongsma, M.A. Sieve element-lining chaperone1 restricts aphid feeding on Arabidopsis during heat stress. Plant Cell 2017, 29, 2450-2464. [CrossRef]

43. Ramírez, C.C.; Niemeyer, H.M. The influence of previous experience and starvation on aphid feeding behavior. J. Insect Behav. 2000, 13, 699-709. [CrossRef]

44. Tjallingii, W.F. Salivary secretions by aphids interacting with proteins of phloem wound responses. J. Exp. Bot. 2006, 57, 739-745. [CrossRef] [PubMed]

45. Will, T.; Tjallingii, W.F.; Thönnessen, A.; van Bel, A.J.E. Molecular sabotage of plant defense by aphid saliva. Proc. Natl. Acad. Sci. USA 2007, 104, 10536-10541. [CrossRef]

46. Garzo, E.; Fernández-Pascual, M.; Morcillo, C.; Fereres, A.; Gómez-Guillamón, M.L.; Tjallingii, W.F. Ultrastructure of compatible and incompatible interactions in phloem sieve elements during the stylet penetration by cotton aphids in melon. Insect Sci. 2018, 25, 631-642. [CrossRef]

47. Lu, Z.Z.; Feng, L.K.; Gao, G.Z.; Gao, L.L.; Han, P.; Sharma, S.; Zalucki, M. Differences in the high-temperature tolerance of Aphis craccivora (Hemiptera: Aphididae) on cotton and soybean: Implications for ecological niche switching among hosts. Appl. Entomol. Zool. 2017, 52, 9-18.

48. Cao, H.H.; Wu, J.; Zhang, Z.F.; Liu, T.X. Phloem nutrition of detached cabbage leaves varies with leaf age and influences performance of the green peach aphid, Myzus persicae. Entomol. Exp. Appl. 2018, 166, 452-459. [CrossRef]

49. Nachappa, P.; Culkin, C.T.; Saya II, P.M.; Han, J.; Nalam, V.J. Water stress modulates soybean aphid performance, feeding behavior, and virus transmission in soybean. Front. Plant Sci. 2016, 7, 552. [CrossRef]

50. Febvay, G.; Bonnin, J.; Rahbé, Y.; Bournoville, R.; Bonnemain, J.L. Resistance of different Lucerne cultivars to the pea aphid Acyrthosiphon pisum: Influence of phloem composition on aphid fecundity. Entomol. Exp. Appl. 2011, 48, 127-134. [CrossRef]

51. Du, R.; Ma, C.S.; Zhao, Q.H.; Ma, G. Effects of heat stress on physiological and biochemical mechanisms of insects: A literature review. Acta Ecol. Sin. 2007, 4, 1565-1572.

52. Cui, J.; Zhu, S.Y.; Gao, Y.; Bi, R.; Xu, Z.; Shi, S.S. Comparative transcriptome analysis of Megacopta cribraria (Hemiptera: Plataspidae) in response to high-temperature stress. J. Econ. Entomol. 2018, 112, 407-415. [CrossRef]

53. Huang, H.J.; Xue, J.; Zhou, J.C.; Cheng, R.L.; Xu, H.J.; Zhang, C.X. Comparative analysis of the transcriptional responses to low and high temperatures in three rice planthopper species. Mol. Ecol. 2017, 26, 2726-2737. [CrossRef]

54. Zhang, B.; Leonard, S.P.; Li, Y.; Moran, N.A. Obligate bacterial endosymbionts limit thermal tolerance of insect host species. Proc. Natl. Acad. Sci. USA 2019, 116, 201915307. [CrossRef] [PubMed] 
55. Burke, G.; Fiehn, O.; Moran, N. Effects of facultative symbionts and heat stress on the metabolome of pea aphids. ISME J. 2010, 4, 242-252. [CrossRef]

56. Leybourne, D.J.; Valentine, T.A.; Bos, J.I.B.; Karley, A.J. A fitness cost resulting from Hamiltonella defensa infection is associated with altered probing and feeding behaviour in Rhopalosiphum padi. J. Exp. Biol. 2020, 223, jeb.207936. [CrossRef]

57. Li, Y.; Zhao, Q.; Duan, X.; Song, C.; Chen, M. Transcription of four Rhopalosiphum padi (L.) heat shock protein genes and their responses to heat stress and insecticide exposure. Comp. Biochem. Phys. A 2017, 205, 48-57. [CrossRef] [PubMed]

58. Will, T.; Schmidtberg, H.; Skaljac, M.; Vilcinskas, A. Heat shock protein 83 plays pleiotropic roles in embryogenesis, longevity, and fecundity of the pea aphid Acyrthosiphon pisum. Dev. Genes Evol. 2017, 227, 1-9. [CrossRef] [PubMed] 